\title{
PENGARUH UMUR KOMPOS RUMAH TANGGA HASIL RANCANG BANGUN FIFO (FIRST IN FIRST OUT) DAN DOSISNYA DALAM MEDIA TANAM DARI LAHAN PASCA TAMBANG TERHADAP PERTUMBUHAN TANAMAN SAWI (Brassica juncea $\mathrm{L}$ )
}

\author{
Benny Kurniawan ${ }^{1}$ \\ ${ }^{1}$ Program Studi Teknik Pertanian, STIPER Kutai Timur. \\ Jl. Soekarno-Hatta No. 01 Sangatta Kutai Timur Kalimantan Timur 75387, Indonesia. \\ E-Mail: bennykurniawan@ stiperkutim.ac.id
}

\begin{abstract}
ABSTRAK
Pengaruh Umur Kompos Rumah Tangga Hasil Rancang Bangun FIFO (First In First Out) dan Dosisnya Dalam Media Tanam Dari Lahan Pasca Tambang Terhadap Pertumbuhan Tanaman Sawi (Brassica juncea L). Penelitian ini bertujuan untuk mengetahui pengaruh umur kompos rumah tangga hasil rancang bangun FIFO (First In First Out) dan penambahan rasio yang optimal antara kompos limbah rumah tangga dan tanah lahan pasca tambang terhadap pertumbuhan tanaman Sawi (Brassicajuncea L). Penelitian dilakukan pada bulan pebruari sampai juni 2016 berlokasi di kota sangatta kab. Kutai Timur.

Penelitian ini merupakan penelitian faktorial yang disusun dengan Rancangan Acak Kelompok dengan 3 Ulangan dua faktor perlakuan, Faktor Pertama adalah umur kompos 3, 6, 9, dan 12 minggu. Faktor Kedua adalah dosis pupuk kompos sampah Rumah tangga 0,10, 20,30, 40, 50, dan 60 ton/ha.

Umur pengkomposan berpengaruh nyata terhadap pertumbuhan tanaman sawi pada tinggi $(\mathrm{cm})$, berat basah (g) dan berat kering (g) tanaman sawi, berpengaruh tetapi tidak nyata pada pertumbuhan jumlah daun tanaman sawi. Dosis kompos campuran tanah pasca tambang sebagai media tanam tanaman sawi berpengaruh nyata terhadap perumbuhan tinggi $(\mathrm{cm})$, Helai daun, berat basah $(\mathrm{g})$ dan berat kering $(\mathrm{g})$. Interaksi antara umur pengkomposan dan dosis pupuk organik pada media tanam tanah pasca tambang memberikan pengaruh nyata terhadap pertumbuhan jumlah daun, berat basah dan berat kering tanaman sawi, tetapi berpengaruh tidak nyata pada pertumbuhan tinggi tanaman sawi. Pupuk organik sampah rumah tangga dengan umur pengkomposan 12 minggu dan dosis 60 ton/ha menghasilkan yang paling tinggi, yaitu tinggi rata rata $35,17 \mathrm{~cm}$, jumlah daun 16 helai, berat basah 60,27 gram, dan berat kering 28,55 gram pada tanaman sawi.
\end{abstract}

Kata kunci : Kompos, pertumbuhan sawi, tanah pasca tambang.

\begin{abstract}
Effect of FIFO (First In First Out) Household Compost Age and Its Dose in Planting Media From Post-Mining Land Against Growth of Mustard (Brassica juncea L). The research aimed was to determine the duration effect of household compost by FIFO (First In First Out) designed and addition an optimal ratio between household waste compost and Post-Mined Land on growth of mustard (Brassica juncea L). Research was conducted on February up to June 2016 and was located in Sangatta city East Kutai Regency.

This research was a factorial research which is arranged in Randomized Block Design with 3 Replications of two treatment factors, First Factor was duration compost of 3, 6, 9, and 12 weeks. The second factor was fertilzer dosage of household waste compost fertilizer $0,10,20,30,40,50$, and 60 ton / ha.

The composting duration had significant effect on growth of height $(\mathrm{cm})$, wet weight $(\mathrm{g})$ and dry weight $(\mathrm{g})$ of mustard, but non significant on growth of number of leaves. The dosage of compost mixed soil of by postmined as planting medium of mustard had significant effect on growth of high $(\mathrm{cm})$, Leaf blade, wet weight $(\mathrm{g})$ and dry weight $(\mathrm{g})$. The interaction between duration of composting and dosage of organic fertilizer on planting medium of post-mined soil had a significant effect on growth of number leaves, wet weight and dry weight of mustard, but non significant effect on high growth of mustard. Household waste organic fertilizers
\end{abstract}


with 12 weeks of composting and dosage 60 tons/ha the highest yield an average $35,17 \mathrm{~cm}$, number of leaves 16 blade, wet weight 60,27 grams, and dry weight 28,55 grams on mustard.

Key words : Compost, growth of Brassica juncea L, post-mining land.

\section{PENDAHULUAN}

Lahan bekas penambangan batubara merupakan lahan marginal yang miskin akan unsur hara, dan hingga saat ini belum banyak dimanfaatkan untuk pengembangan pertanian. Di Kalimantan Timur khususnya kota sangatta kabupaten Kutai Timur potensi lahan bekas penambangan batubara ini cukup luas, dan dapat digunakan untuk pertanian dengan inovasi teknologi pertanian spesifik lokasi.

$$
\text { Perkembangan teknologi }
$$

pengolahan batubara menyebabkan ekstrak bijih kadar rendah menjadi lebih ekonomis, sehingga semakin luas dan semakin dalam mencapai lapisan jauh dibawah permukaan. Hal ini menyebabkan kegiatan pertambangan menimbulkan dampak lingkungan yang sangat besar. Sejalan dengan hal tersebut dan semakin berkembangnya teknologi untuk mengelola alam, maka manusia yang merupakan faktor yang sangat penting dan dominan dalam merestorasi lingkungan menjadi rusak (Arif, 2007).

Lahan bekas penambangan batubara biasanya mempunyai kadar bahan organik yang rendah serta miskin akan unsur hara, membuat tidak banyak tanaman dapat tumbuh dengan baik di lahan tersebut. Tingkat keasaman $(\mathrm{pH})$ atas sampel tanah yang diambil dari lahan pasca tambang di kota sangatta bervariasi dari masam $(\mathrm{pH}=5,8)$ hingga sangat masam $(\mathrm{pH}=4,5)$ serta mempunyai kandungan $\mathrm{C}$ organik tanah yang tergolong sangat rendah, yaitu antara 0,4 $-0,9 \%$.

Kondisi lahan bekas tambang batubara yang rendah bahan organik dan miskin unsur hara dapat diatasi dengan pemberian kompos dan penanaman leguminosa pakan sebagai tanaman penutup tanah. Kebutuhan kompos yang tinggi sementara ketersediaan kompos yang terbatas menyebabkan upaya perbaikan lahan bekas tambang memerlukan dana yang besar.

Pengaruh kegiatan pertambangan mempunyai yang sangat signifikan terutama pencemaran air permukaan dan air tanah, kondisi fisik, kimia dan biologis tanah menjadi buruk seperti lapisan tanah tidak berprofil, terjadi pemadatan, kekurangan unsur hara makro, pH rendah, pencemaran oleh logam-logam berat pada lahan bekas tambang, serta penurunan populasi mikroba tanah.

Pembangunan berwawasan lingkungan menjadi suatu kebutuhan penting bagi setiap bangsa dan negara yang menginginkan kelestarian sumberdaya alam. Oleh sebab itu, sumberdaya alam perlu dijaga dan dipertahankan untuk kelangsungan hidup manusia kini, maupun untuk generasi yang akan datang (Arif, 2007).

Dalam pemrosesan pengomposan sampah rumah tangga selama selama ini mengunakan komposter yang ada yaitu, kompos dicampur antara kompos lama atau yang pertama dimasukkan ke dalam komposter dengan kompos yang baru. Sehingga keseragaman kematangan kompos tidak sama. Berdasarkan uraian di atas diperlukan adanya rancang bangun reaktor kompos skala menengah untuk memproduksi kompos dalam waktu yang singkat, mempunyai kualitas yang baik dan murah sehingga mendukung sistem pengelolaan sampah yang menunjang pertanian ramah lingkungan. Dengan demikian peneliti menguji kompos hasil alat buatan sendiri komposter dengan Sistim FIFO (First In First Out) pertama 
masuk pertama keluar artinya bahwa persediaan yang pertama kali masuk itulah yang pertama kali dikeluarkan atau di panen. Dengan pemanfaatan kompos tersebut nantinya memudahkan masyarakat di dalam melakukan kegiatan bercocok tanam di lahan pasca tambang yang sebelumnya belum dimanfaatkan secara maksimal.

Penelitian ini dilakukan untuk menguji kompos limbah rumah tanga yang dihasilkan dari rancang bangun FIFO (First In First Out) dan tanah pasca tambang dengan mengunakan tanaman Sawi (Brassica juncea L) sebagai tanaman uji. Tujuan penelitian adalah untuk mengetahui pengaruh umur kompos rumah tangga dan penambahan rasio yang optimal antara kompos limbah rumah tangga dan tanah lahan pasca tambang terhadap pertumbuhan tanaman Sawi (Brassicajuncea L).

\section{METODA PENELITIAN}

\subsection{Tempat dan Waktu}

Tempat kota Sangatta kabupaten Kutai Timur Meliputi pembuatan kompos, uji penanaman Sawi varietas TOSAKAN dengan komposisi media tanam yang berbeda, serta uji komposisi Kompos Laboraturium tanah dan air Program Studi Manajemen Hutan Jurusan Manajemen Pertanian Politeknik Pertanian Negeri Samarinda. Pada bulan Februari-Juni 2016.

\subsection{Bahan dan Alat}

Bahan yang digunakan adalah sampah organik (sampah sisa rumah tangga), EM4 (bakteri pengurai), benih Sawi (Brassica juncea. L.) varietas Tosakan, polibag ukuran $40 \mathrm{~cm}$ x 40 $\mathrm{cm}$. Sedangkan alat yang digunakan adalah cangkul, sabit, polibag, tray, meteran, timbangan, jangka sorong, ajir, gunting, oven dan komposter sistem FIFO (first in first out).

\subsection{Metode Penelitian}

Penelitian ini merupakan penelitian faktorial yang disusun dengan Rancangan acak Kelompok dengan 3 ulangan dua faktor perlakuan, sebagai berikut :

Faktor Pertama adalah umur kompos (U)

$$
\begin{array}{ll}
- & \mathrm{u} 1=3 \text { Minggu } \\
- & \mathrm{u} 2=6 \text { Minggu } \\
- & \mathrm{u} 3=9 \text { Minggu } \\
- & \mathrm{u} 4=12 \mathrm{Minggu}
\end{array}
$$

Faktor Kedua adalah dosis pupuk kompos sampah Rumah tangga (D)

$$
\begin{aligned}
- & \mathrm{d} 0=0 \mathrm{Ton} / \mathrm{Ha} \\
- & \mathrm{d} 1=10 \mathrm{Ton} / \mathrm{Ha} \\
- & \mathrm{d} 2=20 \mathrm{Ton} / \mathrm{Ha} \\
- & \mathrm{d} 3=30 \mathrm{Ton} / \mathrm{Ha} \\
- & \mathrm{d} 4=40 \mathrm{Ton} / \mathrm{Ha} \\
- & \mathrm{d} 5=50 \mathrm{Ton} / \mathrm{Ha} \\
- & \mathrm{d} 6=60 \mathrm{Ton} / \mathrm{Ha}
\end{aligned}
$$

Model rancangan linier yang digunakan adalah sebagai berikut :

$Y_{i j k}=\boldsymbol{\mu}+\boldsymbol{a}_{i}+\boldsymbol{b}_{j}+(\boldsymbol{a b})_{i j}+\boldsymbol{p}_{k}+\sum_{i j k}$

Keterangan :

$\mathbf{Y}_{\mathbf{i j k}}=$ Nilai pengamatan pada, Dosis

kompos ke-i dan tingkat Umur kompos ke-j, ulangan ke-k

$\boldsymbol{\mu}=$ Nilai rataan umum

$\mathbf{a}_{\mathbf{i}}=$ Pengaruh dosis kompos ke-j $(i=1,2,3, .$.

$\mathbf{b}_{\mathbf{j}}=$ Pengaruh umur kompos ke-k $(\mathrm{j}=1,2,3, .$.

$(\mathbf{a b})_{\mathrm{ij}}=$ Pengaruh interaksi pemberian kompus dosis pupuk pada taraf ke-i dan umur kompos pada taraf ke-j

$\mathbf{p}_{\mathbf{k}}=$ Pengaruh ulangan ke-i $(\mathrm{i}=1,2,3 .$.

$\sum_{\mathrm{ij}}=$ Pengaruh galat pada blok ke-i yang mendapat perlakuan umur pengkomposan pupuk pada taraf ke-j dan pemberian dosis pupuk organik pada taraf ke-k

Data yang diperoleh di analisis ragam (Uji Fisher) pada taraf 5\% dan apabila terdapat perbedaan yang nyata 
dilanjutkan dengan Uji Beda Nyata Terkecil (BNT) pada taraf 5\%.

\section{HASIL PENELITIAN DAN PEMBAHASAN}

\subsection{Kualitas Kompos}

Penelitian dilaksanakan dengan menggunakan unit komposter FIFO dari tong plastik hasil rakitan tim peneliti.
Pengamatan dilakukan setiap seminggu sekali untuk mengetahui produksi kompos dihasilkan. Pada penelitian ini dilakukan juga pemeriksaan di laboratorium Tanah dan Air Prgram Studi Manajemen Hutan Jurusan Manajemen Pertanian Politeknik Pertanian Negeri Samarinda terhadap kualitas kompos yang dihasilkan pada tanggal 28 mei 2016.

Tabel 1. Hasil Analisa Laboraturium Kandungan Kimia Kompos Rumah Tangga

\begin{tabular}{lrrrrr}
\hline Sifat Kimia & $\begin{array}{c}\text { Tanah Pasca } \\
\text { Tambang }\end{array}$ & $\begin{array}{c}\text { Kompos 3 } \\
\text { minggu }\end{array}$ & $\begin{array}{c}\text { Kompos 6 } \\
\text { minggu }\end{array}$ & $\begin{array}{c}\text { Kompos 9 } \\
\text { minggu }\end{array}$ & $\begin{array}{c}\text { Kompos 12 } \\
\text { minggu }\end{array}$ \\
\hline pH & 3,890 & 7,230 & 7,530 & 7,350 & 7,580 \\
P (\%) & 0,008 & 0,103 & 0,104 & 0,105 & 0,157 \\
K (\%) & 0,069 & 0,287 & 0,224 & 0,229 & 0,290 \\
N (\%) & 0,210 & 0,875 & 0,840 & 0,910 & 1,540 \\
C Organik (\%) & 4,030 & 17,790 & 17,000 & 16,070 & 16,120 \\
C / N & $\mathbf{1 9 , 1 9 0}$ & $\mathbf{2 0 , 3 3 1}$ & $\mathbf{2 0 , 2 3 8}$ & $\mathbf{1 7 , 6 5 9}$ & $\mathbf{1 0 , 4 6 8}$ \\
Kadar Abu & 93,050 & 69,320 & 70,700 & 72,300 & 72,210 \\
Cu (ppm) & 14,200 & 18,900 & 19,800 & 17,600 & 15,400 \\
Fe (ppm) & 28,700 & 23,300 & 31,200 & 17,400 & 73,300 \\
Zn (ppm) & 21,120 & 67,130 & 60,820 & 58,560 & 68,320 \\
Mn (ppm) & ttd & ttd & ttd & ttd & ttd \\
\hline
\end{tabular}

Sumber : Laboraturium Tanah dan Air Politeknik Pertanian Negeri Samarinda 2016

3.2. Tanaman Sawi (Brassica juncea L.).

\subsubsection{Tinggi Tanaman Sawi.}

Dua (2) Minggu Setelah Tanam.
Pengaruh dosis kompos dan umur pengkomposan terhadap pertumbuhan (tinggi) tanaman sawi pada 2 MST disajikan pada Tabel 2.

Tabel 2. Pengaruh Dosis Kompos Rumah Tangga pada Media Tanam dan Umur Pengkomposan serta interaksinya Terhadap Tinggi Tanaman Sawi (cm) pada 2 Minggu Setelah Tanam.

\begin{tabular}{|c|c|c|c|c|c|}
\hline \multirow{2}{*}{$\begin{array}{c}\text { Dosis Pupuk } \\
\text { Kompos (ton/ha) }\end{array}$} & \multicolumn{4}{|c|}{ Umur Pengkomposan (minggu) } & \multirow{2}{*}{ Rerata } \\
\hline & 3 & 6 & 9 & 12 & \\
\hline 0 & 3,77 & 3,87 & 3,70 & 4,10 & $3,86 \mathrm{~d}$ \\
\hline 10 & 3,21 & 4,01 & 3,93 & 3,75 & $3,73 \mathrm{~d}$ \\
\hline 20 & 3,80 & 4,40 & 3,94 & 3,86 & $4,00 \mathrm{~cd}$ \\
\hline 30 & 3,91 & 4,69 & 4,62 & 4,65 & $4,47 \mathrm{bc}$ \\
\hline 40 & 4,86 & 4,93 & 4,78 & 4,84 & $4,85 \mathrm{ab}$ \\
\hline 50 & 4,13 & 5,13 & 4,71 & 5,13 & $4,77 \mathrm{ab}$ \\
\hline 60 & 5,00 & 4,83 & 5,28 & 4,97 & 5,02 a \\
\hline Rerata & 4,10 & 4,55 & 4,43 & 4,47 & \\
\hline
\end{tabular}

BNT 0,05\% Dosis $=\mathbf{0 , 0 5}$ 
Dosis pupuk kompos berpengaruh sangat nyata terhadap tinggi tanaman sawi pada pengamatan 2 MST, tetapi perlakuan umur pengkomposan dan interaksi Tiga (3) Minggu Setelah Tanam

Pengaruh dosis kompos dan umur pengkomposan terhadap pertumbuhan keduanya (perlakuan dosis pupuk kompos dengan umur pengkomposan) berpengaruh tidak nyata.

(tinggi) tanaman sawi pada 3 MST disajikan pada Tabel 3.

Tabel 3. Pengaruh Dosis Kompos Rumah Tangga pada Media Tanam dan Umur Pengkomposan Serta Interaksinya Terhadap Tinggi Tanaman Sawi (cm) pada 3 Minggu Setelah Tanam

\begin{tabular}{cllcll}
\hline \multirow{2}{*}{$\begin{array}{c}\text { Dosis pupuk } \\
\text { kompos (ton/ha) }\end{array}$} & \multicolumn{4}{c}{ Umur Pengkomposan (Minggu) } & \multirow{2}{*}{ Rerata } \\
\cline { 2 - 5 } 0 & $5,76 \mathrm{k}$ & $6,34 \mathrm{ijk}$ & $6,66 \mathrm{ghijk}$ & $7,07 \mathrm{ghijk}$ & $6,46 \mathrm{e}$ \\
10 & $6,56 \mathrm{hijk}$ & $6,47 \mathrm{hijk}$ & $7,15 \mathrm{fghij}$ & $7,71 \mathrm{efgh}$ & $6,98 \mathrm{de}$ \\
20 & $6,91 \mathrm{ghijk}$ & $6,26 \mathrm{ijk}$ & $7,73 \mathrm{efgh}$ & $8,44 \mathrm{def}$ & $7,33 \mathrm{~cd}$ \\
30 & $6,02 \mathrm{jk}$ & $7,50 \mathrm{fghi}$ & $7,95 \mathrm{efg}$ & $9,33 \mathrm{bcd}$ & $7,70 \mathrm{c}$ \\
40 & $7,04 \mathrm{ghijk}$ & $10,11 \mathrm{bc}$ & $8,95 \mathrm{cde}$ & $9,75 \mathrm{bcd}$ & $8,96 \mathrm{~b}$ \\
50 & $8,90 \mathrm{cde}$ & $10,62 \mathrm{ab}$ & $9,58 \mathrm{bcd}$ & $10,48 \mathrm{ab}$ & $9,89 \mathrm{a}$ \\
60 & $10,57 \mathrm{ab}$ & $11,52 \mathrm{a}$ & $9,80 \mathrm{bc}$ & $9,80 \mathrm{bc}$ & $10,42 \mathrm{a}$ \\
\hline Rerata & $7,39 \mathrm{c}$ & $8,40 \mathrm{~b}$ & $8,26 \mathrm{~b}$ & $8,94 \mathrm{a}$ & \\
\hline BNT 0,05\% Dosis $=$ & 0,$67 ;$ Umur Pengkomposan $=0,51 ;$ Interaksi Umur\&Dosis $=1,35$
\end{tabular}

Keterangan: Angka pada daerah yang tidak diarsir yang diikuti dengan huruf yang sama menunjukkan tidak berbeda nyata (Uji BNT $\square=5 \%$ ), angka pada baris/kolom yang diarsir yang diikuti dengan huruf yang sama menunjukkan tidak berbeda nyata (Uji BNT $\square=5 \%$ ), KK $=9,99 \%$.

Dosis pupuk kompos, umur pengkomposan dan interaksi keduanya berpengaruh sangat nyata terhadap tinggi tanaman sawi pada pengamatan 3 MST.

Berdasarkan perhitungan, nilai BNT 5\% pada pada tabel 2 diperoleh uji lanjut Empat (4) Minggu Setelah Tanam

Pengaruh dosis kompos dan umur pengkomposan terhadap pertumbuhan (tinggi) tanaman sawi pada 4 MST disajikan pada Tabel 4.
BNT dosis pupuk kompos $=0,67$, umur pengkomposan $=0,51$ dan interaksi (umur pengkomposan dan dosis pupuk kompos) $=1,35$.

Dosis pupuk kompos, umur pengkomposan berpengaruh sangat nyata terhadap tinggi tanaman sawi pada pengamatan 4 MST 
Tabel 4. Pengaruh Dosis Kompos Rumah Tangga pada Media Tanam dan Umur Pengkomposan serta interaksinya Terhadap Tinggi Tanaman Sawi $(\mathrm{cm})$ pada 4 Minggu Setelah Tanam

\begin{tabular}{|c|c|c|c|c|c|}
\hline \multirow{2}{*}{$\begin{array}{l}\text { Dosis } \quad \text { Pupuk } \\
\text { Kompos (ton/ha) }\end{array}$} & \multicolumn{4}{|c|}{ Umur Pengkomposan (Minggu) } & \multirow{2}{*}{ Rerata } \\
\hline & 3 & 6 & 9 & 12 & \\
\hline 0 & 25,20 & 24,00 & 25,67 & 24,99 & $24,96 \mathrm{e}$ \\
\hline 10 & 24,28 & 25,04 & 24,58 & 25,83 & $24,93 \mathrm{e}$ \\
\hline 20 & 28,67 & 26,69 & 26,68 & 26,32 & $27,09 \mathrm{~d}$ \\
\hline 30 & 32,95 & 29,60 & 29,46 & 29,96 & $30,49 \mathrm{c}$ \\
\hline 40 & 29,00 & 28,00 & 30,25 & 30,73 & $29,50 \mathrm{c}$ \\
\hline 50 & 35,01 & 31,83 & 32,75 & 33,38 & $33,24 \mathrm{~b}$ \\
\hline 60 & 36,92 & 35,37 & 34,48 & 35,17 & $35,49 \mathrm{a}$ \\
\hline Rerata & $30,29 \mathrm{a}$ & $28,65 \mathrm{~b}$ & $29,12 \mathrm{~b}$ & $29,48 \mathrm{ab}$ & \\
\hline
\end{tabular}

Keterangan: Angka rata-rata pada kolom/baris yang diarsir diikuti dengan huruf yang sama menunjukkan tidak berbeda nyata (Uji BNT, $\alpha=5 \%$ ). $\mathrm{KK}=4,6 \%$

Dosis pupuk kompos, umur pengkomposan berpengaruh sangat nyata terhadap tinggi tanaman sawi pada pengamatan 4 MST.

Sedangkan interaksi keduanya (perlakuan umur pengkomposan dan dosis pupuk kompos) berpengaruh tidak nyata. Berdasarkan perhitungan, nilai BNT 5\% ada pada tabel 3 diperoleh uji lanjut BNT dosis pupuk kompos $=0,84$, umur pengkomposan $=1,1$.

\subsubsection{Jumlah Daun Tanaman Sawi}

Dua (2) Minggu Masa tanam

Tiga (3) Minggu Masa tanam Pengaruh dosis kompos dan umur pengkomposan terhadap pertumbuhan
Pengaruh dosis kompos dan umur pengkomposan terhadap pertumbuhan (jumlah daun) tanaman sawi pada 2 MST baik perlakuan dosis pupuk kompos, umur pengkomposan dan interaksi keduanya (perlakuan dosis pupuk kompos dengan umur pengkomposan) berpengaruh tidak nyata sehingga tidak uji lanjut BNT.

Jumlah daun tanaman sawi terbanyak diperoleh pada kombinasi antara dosis pupuk kompos $(2,67)$ dan jumlah daun tanaman sawi terendah diperoleh pada kombinasi antara dosis pupuk kompos (2).

(jumlah daun) tanaman sawi pada 3 MST disajikan pada Tabel 5. 
Tabel 5. Pengaruh Dosis Kompos Rumah Tangga pada Media Tanam dan Umur Pengkomposan serta interaksinya Terhadap Jumlah Daun Tanaman Sawi pada 3 Minggu Setelah Tanam.

\begin{tabular}{cccccc}
\hline \multirow{2}{*}{$\begin{array}{c}\text { Dosis Pupuk Kompos } \\
\text { (ton/ha) }\end{array}$} & $\mathbf{3}$ & $\mathbf{6}$ & $\mathbf{9}$ & \multirow{2}{*}{ Rerata } \\
\cline { 2 - 5 } & 3,67 & 3,33 & 3,33 & $\mathbf{1 2}$ & \\
\hline $\mathbf{0}$ & 4,00 & 3,67 & 3,33 & 3,00 & $3,33 \mathrm{c}$ \\
$\mathbf{1 0}$ & 3,33 & 4,00 & 3,33 & 3,67 & $3,58 \mathrm{c}$ \\
$\mathbf{3 0}$ & 3,67 & 3,33 & 4,00 & 3,00 & $3,50 \mathrm{c}$ \\
$\mathbf{4 0}$ & 4,00 & 3,33 & 3,67 & 3,67 & $3,67 \mathrm{bc}$ \\
$\mathbf{5 0}$ & 4,00 & 3,67 & 4,00 & 4,67 & $4,08 \mathrm{ab}$ \\
$\mathbf{6 0}$ & 4,00 & 4,67 & 4,67 & 4,67 & $4,50 \mathrm{a}$ \\
\hline Rerata & 3,81 & 3,71 & 3,76 & 3,76 & \\
\hline BNT 0,05\% Dosis $=\mathbf{0 , 4 3}$ & & & & \\
\hline
\end{tabular}

Keterangan: Angka rata-rata pada kolom/baris yang diarsir diikuti dengan huruf yang sama menunjukkan tidak berbeda nyata (Uji BNT, $\alpha=5 \%$ ). KK $=14,1 \%$.

Dosis pupuk kompos berpengaruh sangat nyata terhadap jumalah daun tanaman sawi pada pengamatan 3 MST, tetapi perlakuan umur pengkomposan dan interaksi keduanya (perlakuan dosis pupuk kompos dengan umur pengkomposan)

Empat (4) Minggu Masa tanam

Pengaruh dosis kompos dan umur pengkomposan terhadap pertumbuhan (jumlah daun) tanaman sawi pada 4 MST disajikan pada Tabel 6 .

Dosis pupuk kompos, umur pengkomposan dan interaksi keduanya berpengaruh sangat nyata terhadap berpengaruh tidak nyata lebih jelasnya dapat dilihat tabel analisis sidik ragam di Lampiran 4. Berdasarkan perhitungan, nilai BNT 5\% pada pada tabel 4.1 diperoleh uji BNT Dosis $=0,43$.

jumlah daun tanaman sawi pada pengamatan 4 MST. Berdasarkan perhitungan, nilai BNT 5\% pada pada tabel 6 diperoleh uji lanjut BNT dosis pupuk kompos $=0,65$, umur pengkomposan $=0,49$ dan interaksi (umur pengkomposan dan dosis pupuk kompos) $=1,31$.

Tabel 6. Pengaruh Dosis Kompos Rumah Tangga pada Media Tanam dan Umur Pengkomposan serta interaksinya Terhadap Jumlah Daun Tanaman Sawi pada 4 Minggu Setelah Tanam.

\begin{tabular}{|c|c|c|c|c|c|}
\hline \multirow{2}{*}{$\begin{array}{c}\text { Dosis Pupuk Kompos } \\
\text { (ton/ha) }\end{array}$} & \multicolumn{4}{|c|}{ Umur Pengkomposan (Minggu) } & \multirow{2}{*}{ Rerata } \\
\hline & 3 & 6 & 9 & 12 & \\
\hline 0 & $4,33 \mathrm{mn}$ & $4,33 \mathrm{mn}$ & $4,00 \mathrm{n}$ & $4,33 \mathrm{mn}$ & $4,25 \mathrm{f}$ \\
\hline 10 & $5,33 \mathrm{~lm}$ & $6,00 \mathrm{jkl}$ & $5,67 \mathrm{kl}$ & $6,67 \mathrm{ijk}$ & $5,92 \mathrm{e}$ \\
\hline 20 & $5,33 \mathrm{~lm}$ & $5,67 \mathrm{kl}$ & $6,00 \mathrm{jkl}$ & $6,67 \mathrm{ijk}$ & $5,92 \mathrm{e}$ \\
\hline 30 & $6,67 \mathrm{ijk}$ & 7,00 hij & $8,00 \mathrm{fgh}$ & $9,67 \mathrm{de}$ & $7,83 \mathrm{~d}$ \\
\hline 40 & 7,33 ghi & 7,33 ghi & $10,67 \mathrm{~cd}$ & $11,33 \mathrm{c}$ & $9,17 \mathrm{c}$ \\
\hline 50 & 8,67 ef & 9,67 de & $13,33 \mathrm{~b}$ & $14,33 \mathrm{~b}$ & $11,50 \mathrm{~b}$ \\
\hline 60 & $8,33 \mathrm{fg}$ & $10,33 \mathrm{~cd}$ & $15,67 \mathrm{a}$ & $15,67 \mathrm{a}$ & $12,50 \mathrm{a}$ \\
\hline Rerata & $6,57 \mathrm{~d}$ & $7,19 \mathrm{c}$ & $9,05 \mathrm{~b}$ & $9,81 \mathrm{a}$ & \\
\hline
\end{tabular}


Keterangan: Angka pada daerah yang tidak diarsir yang diikuti dengan huruf yang sama menunjukkan tidak berbeda nyata (Uji BNT $\square=5 \%$ ), angka pada baris/kolom yang diarsir yang diikuti dengan huruf yang sama menunjukkan tidak berbeda nyata (Uji BNT $\alpha=5 \%$ ). KK $=9,8 \%$

\subsubsection{Berat Basah dan Kering}

\section{Berat Basah}

Pengaruh dosis kompos dan umur pengkomposan terhadap pertumbuhan (berat basah) tanaman sawi pada saat panen disajikan pada Tabel 7.

Dosis pupuk kompos, umur pengkomposan dan interaksi keduanya berpengaruh sangat nyata terhadap berat basah tanaman sawi pada masa panen. Berdasarkan perhitungan, nilai BNT 5\% pada pada tabel 7 diperoleh uji lanjut BNT dosis pupuk kompos $=0,89$, umur pengkomposan $=0,67$ dan interaksi (umur pengkomposan dan dosis pupuk kompos) $=1,78$.

Tabel 7. Pengaruh Dosis Kompos Rumah Tangga pada Media Tanam dan Umur Pengkomposan serta interaksinya Terhadap Berat Basah Tanaman Sawi.

\begin{tabular}{|c|c|c|c|c|c|}
\hline \multirow{2}{*}{$\begin{array}{c}\text { Dosis Pupuk } \\
\text { Kompos (ton/ha) }\end{array}$} & \multicolumn{4}{|c|}{ Umur Pengkomposan (Minggu) } & \multirow{2}{*}{ Rerata } \\
\hline & 3 & 6 & 9 & 12 & \\
\hline 0 & $6,09 \mathrm{~m}$ & $6,63 \mathrm{~m}$ & $6,12 \mathrm{~m}$ & $5,92 \mathrm{~m}$ & $6,19 \mathrm{~g}$ \\
\hline 10 & 11,621 & 11,631 & $12,64 \mathrm{kl}$ & $13,25 \mathrm{jkl}$ & $12,28 \mathrm{f}$ \\
\hline 20 & $13,64 \mathrm{jk}$ & $13,21 \mathrm{jkl}$ & $14,56 \mathrm{ij}$ & $15,91 \mathrm{i}$ & $14,33 \mathrm{e}$ \\
\hline 30 & $13,57 \mathrm{jk}$ & $13,84 \mathrm{jk}$ & $19,00 \mathrm{~h}$ & $19,63 \mathrm{~h}$ & $16,51 \mathrm{~d}$ \\
\hline 40 & $13,58 \mathrm{jk}$ & $18,86 \mathrm{~h}$ & $27,30 \mathrm{~g}$ & $28,11 \mathrm{~g}$ & $21,96 \mathrm{c}$ \\
\hline 50 & $26,96 \mathrm{~g}$ & $32,07 \mathrm{f}$ & $43,29 c$ & $49,24 \mathrm{~b}$ & $37,89 \mathrm{~b}$ \\
\hline 60 & $35,74 \mathrm{e}$ & $41,16 \mathrm{~d}$ & $59,81 \mathrm{a}$ & $60,27 \mathrm{a}$ & $49,25 \mathrm{a}$ \\
\hline Rerata & $17,31 \mathrm{~d}$ & $19,63 \mathrm{c}$ & $26,10 \mathrm{~b}$ & $27,48 \mathrm{a}$ & \\
\hline
\end{tabular}

Keterangan: Angka pada daerah yang tidak diarsir yang diikuti dengan huruf yang sama menunjukkan tidak berbeda nyata (Uji BNT $\square=5 \%$ ), angka pada baris/kolom yang diarsir yang diikuti dengan huruf yang sama menunjukkan tidak berbeda nyata (Uji BNT $\square=5 \%$ ), $\mathrm{KK}=4,8 \%$.

\section{Berat Kering}

Pengaruh dosis kompos dan umur pengkomposan terhadap pertumbuhan (berat basah) tanaman sawi pada saat panen disajikan pada Tabel 8.

Dosis pupuk kompos, umur pengkomposan dan interaksi keduanya berpengaruh sangat nyata terhadap berat kering tanaman sawi pada masa panen.

Berdasarkan perhitungan, nilai BNT 5\% pada pada tabel 8 diperoleh uji lanjut BNT dosis pupuk kompos $=0,57$, umur pengkomposan $=0,43$ dan interaksi (umur pengkomposan dan dosis pupuk kompos) $=1,14$. 
Tabel 8. Pengaruh Dosis Kompos Rumah Tangga pada Media Tanam dan Umur Pengkomposan serta interaksinya Terhadap Berat Kering Tanaman Sawi.

\begin{tabular}{|c|c|c|c|c|c|}
\hline \multirow{2}{*}{$\begin{array}{c}\text { Dosis Pupuk Kompos } \\
\text { (ton/ha) }\end{array}$} & \multicolumn{4}{|c|}{ Umur Pengkomposan (Minggu) } & \multirow{2}{*}{ Rerata } \\
\hline & 3 & 6 & 9 & 12 & \\
\hline 0 & $1,31 \mathrm{~lm}$ & $1,37 \mathrm{~lm}$ & $1,32 \mathrm{~lm}$ & $1,17 \mathrm{~m}$ & $1,29 \mathrm{f}$ \\
\hline 10 & $2,66 \mathrm{jk}$ & $2,74 \mathrm{jk}$ & $2,74 \mathrm{jk}$ & $2,73 \mathrm{jk}$ & $2,72 \mathrm{e}$ \\
\hline 20 & $2,63 \mathrm{jk}$ & $2,40 \mathrm{kl}$ & $3,30 \mathrm{jk}$ & $3,39 \mathrm{jk}$ & $2,93 \mathrm{e}$ \\
\hline 30 & $3,47 \mathrm{ijk}$ & $3,03 \mathrm{jk}$ & $4,55 \mathrm{hi}$ & $4,61 \mathrm{hi}$ & $3,92 \mathrm{~d}$ \\
\hline 40 & $3,67 \mathrm{ij}$ & $4,81 \mathrm{gh}$ & $5,66 \mathrm{fgh}$ & $6,18 \mathrm{f}$ & $5,08 \mathrm{c}$ \\
\hline 50 & $8,34 \mathrm{e}$ & $5,90 \mathrm{fg}$ & $10,48 \mathrm{~d}$ & $18,79 \mathrm{c}$ & $10,88 \mathrm{~b}$ \\
\hline 60 & $5,09 \mathrm{fgh}$ & $7,49 \mathrm{e}$ & $26,75 \mathrm{~b}$ & $28,55 \mathrm{a}$ & $16,97 \mathrm{a}$ \\
\hline Rerata & $3,88 \mathrm{c}$ & $3,96 \mathrm{c}$ & $7,83 \mathrm{~b}$ & $9,35 \mathrm{a}$ & \\
\hline BNT 0,05\% Dosis = & \multicolumn{5}{|c|}{ 0,57; Umur Pengkomposan = 0,43; Interaksi Umur\&Dosis $=1,14$} \\
\hline
\end{tabular}

Keterangan: Angka pada daerah yang tidak diarsir yang diikuti dengan huruf yang sama menunjukkan tidak berbeda nyata (Uji BNT $\square=5 \%$ ), angka pada baris/kolom yang diarsir yang diikuti dengan huruf yang sama menunjukkan tidak berbeda nyata (Uji BNT $\square=5 \%$ ), $\mathrm{KK}=11,3 \%$.

Hasil analisa laboratorium terhadap pupuk organik sampah rumah tangga berdasarkan umur pengkomposan dan tanah pasca tambang yang dihasilkan menunjukkan nilai yang bervariasi. Dilihat dari hasil uji laboraturium parameter unsur hara makro berupa nitrogen, karbon, Phosfor (P2O5), C/Nrasio, dan Kalium (K2O), tanah pasca tambang bahwa menunjukkan kandungan unsur hara makro di bawah nilai minimal standar SNI 19-7030-2004 dan bersifat asam $(\mathrm{pH}=3,89)$. Sedangkan hasil uji kompos berdasarkan umur pengkomposan 3, 6, 9, dan 12 minggu menunjukkan kandungan unsur hara makro semuanya diatas nilai minimal SNI 19-7030-2004 dan nilai $\mathrm{pH}$ kisaran 7,2 - 7,6 (bersifat netral), sedangkan untuk parameter rasio $\mathrm{C} / \mathrm{N}$ kompos relatif telah memenuhi standar minimal kualitas pupuk sesuai SNI tersebut dapat dilihat di (Badan Standardisasi Nasional, 2004), lebih jelasnya dapat dilihat di Tabel Standar Nasional Indonesia 19-7030-
2004 Lampiran 1. Apabila dilihat berdasarkan Permentan 70-2011 maka kompos dihasilkan (umur 3, 6, 9, dan 12 minggu ) komposter FIFO yaitu kandungan unsur makro $(\mathrm{N}+$ $\mathrm{P} 2 \mathrm{O} 5+\mathrm{K} 2 \mathrm{O}$ ) dibawah nilai minimal yang di tetapkan 4\% Persyaratan Teknis Minimal Pupuk Organik Padat di lampran 2, hal ini menjelaskan kompos hasil komposter FIFO masih belum memenuhi standart kementan diduga kandungan unsur hara makro dipengaruhi dengan bahan organik sampah pada rumah tangga yang digunakan.

Setiap organisme pendegradasian bahan organik membutuhkan kondisi lingkungan dan bahan yang berbedabeda. Apabila kondisi sesuai, maka dekomposer tersebut akan bekerja giat untuk mendekomposisi limbah padat organik. Apabila kondisinya kurang sesuai atau tidak sesuai, maka organisme tersebut akan dorman, pindah ke tempat lain, atau bahkan mati. Rasio $\mathrm{C} / \mathrm{N}$ yang efektif untuk proses pengomposan 
berkisar antara 10-20 sangat efisien untuk pengomposan. Mikroba memecah senyawa $\mathrm{C}$ sebagai sumber energi dan menggunakan $\mathrm{N}$ untuk sintesis protein. Apabila rasio $\mathrm{C} / \mathrm{N}$ terlalu tinggi atau bahan organik miskin akan Nitrogen maka aktivitas mikroorganisme dalam mendegradasi bahan akan menurun, sehingga pengomposan akan berjalan lambat. Apabila rasio $\mathrm{C} / \mathrm{N}$ rendah maka waktu yang dibutuhkan untuk pengomposan semakin singkat (Pitoyo, 2016).

Umumnya tanaman sawi dibudidayakan pada lahan terbuka. Tanaman sawi untuk pertumbuhannya menginginkan tanah yang gembur, banyak mengandung humus (subur), dan drainasenya baik. Sedangkan derajat keasaman yang dikehendaki tanaman sawi adalah 6-7 dan suhu udara yang diinginkan oleh tanaman sawi untuk pertumbuhan adalah 20 0C -28 0C (Gustia, 2014). Dengan berkembangnya pemanfaatan lahan bekas penambangan batubara yang telah mulai di reklamasi di kota sangatta maka dicoba menjadi alternatif lahan pertanian yang mengunakan tanaman semusim sawi. Penambahan mengunakan pupuk kompos organik sampah rumah tangga pada tanah pasca tambang merupakan salah satu cara meningkatkan tingkat kesuburan media tanam dengan menaikkan kandungan organik dan unsur hara.

Pertambahan tinggi tanaman adalah salah satu bagian dari pertumbuhan. Parameter ini menjadi salah satu yang diamati untuk mengukur pengaruh tiap perlakuan yang diberikan pada sampel penelitian.

Hasil pengamatan menunjukkan bahwa ada perbedaan tinggi tanaman antara tiap perlakuan. Pemberian dosis pupuk organik sampah rumah tangga 60 ton/ha memberikan pengaruh pertumbuhan tinggi tanaman lebih baik dibanding dengan dosis lainya $(0,10,20$,
30, 40, dan 50 ton/ha). Hal ini diduga bahwa pengaruh kandungan zat hara pada pupuk organik sampah rumah tangga terdapat $\mathrm{N} 1,54 \%, \mathrm{P} 0,157 \%, \mathrm{~K} \quad 0,29 \%$, dan $\mathrm{C}$ organik $16,12 \%$, sehingga jumlah nutrisi yang diberikan tanaman sawi melalui media tanam dengan konsentrasi 60 ton/ha menunjukkan pengaruh terhadap pertumbuhan tinggi tanaman.

Pemberian dosis pupuk organik sampah rumah tangga pada media tanam tanah pasca tambang batubara bukan hanya menambah kandungan unsur hara yang sangat di butuhkan oleh tanaman sawi, juga memberikan perbaikan keadaan struktur yang lebih longgar dan lepas sehingga dapat memberikan ruang gerak pada mikroorganisme di dalam tanah. Dan jika kandungan nitrogen yang tersedia di dalam tanah dan mencukupi kebutuhan tanaman, dapat meningkatkan tinggi tanaman, sehingga tanaman dapat tumbuh dengan baik. Sebaliknya tanaman tidak dapat tumbuh dengan baik jika unsur hara nitorgen tidak tercukupi pada tanaman. Pernyataan ini diperkuat oleh Suleman, D \& Dkk (2013), bahwa kekurangan unsur hara nitrogen menyebabkan tanaman tumbuh kerdil dan pertumbuhannya tersendat, serta daun berwarna hijau muda dan akhirnya kuning.

Jumlah helai daun tanaman sawi menjadi salah satu yang diamati untuk mengukur pengaruh tiap perlakuan yang diberikan pada sampel penelitian. Hasil pengamatan menunjukkan bahwa ada perbedaan jumlah daun tanaman antara tiap perlakuan. Pemberian dosis pupuk organik sampah rumah tangga memberikan pengaruh berbeda setiap pengamatan minggu setelah tanam, pada pengamatan 2 MST pemberian dosis pupuk kompos belum memberikan pengaruh pertumbuhan jumlah daun tanaman sawi, sedangkan pengamatan 3 dan 4 MST perlakuan dosis 60 ton/ha mulai memberi pengaruh lebih baik 
dibanding dengan dosis lainya $(0,10,20$, 30, 40, dan 50 ton/ha).

Pengamatan pada berat basah dan berat kering tanaman sawi untuk mengukur pengaruh tiap perlakuan yang diberikan pada sampel penelitian. Perlakuan umur pengkomposan dan pemberian dosis pupuk organik sampah rumah tangga memberikan pengaruh pertumbuhan berat basah dan berat kering tanaman sawi. Diduga perlakuan pemberian pupuk sampah organik rumah tangga dan umur pengkomposan. Berat segar tanaman terdiri dari $80-90 \%$ adalah air dan sisanya adalah berat kering. Kemampuan tanaman dalam menyerap air terletak pada akarnya. Kondisi akar yang baik akan mendukung penyerapan air yang optimal (Wahid \& dkk, 2013).

Berdasarkan penggunaan

komposter FIFO dalam proses pengkomposan secara terus menerus pupuk organik dari samah rumah tangga yang menghasilkan kompos dengan tingkat keseragaman kematangan baik dan memenuhi standard minimal SNI 197030-2004. Tetapi masih belum standar jumlah persentasi minimal permentan nomor 70/Permentan/SR.140/10/2011.

Dilihat dari semua pengamatan pengaruh perlakuan dosis dan umur pengkomposan terhadap pertumbuhan dan produksi tanaman sawi (Brassica juncea L.). Hasil dari perhitungan uji lanjut BNT 5\% serta grafik menjelaskan bahwa semua perlakuan pada penelitian memberikan pengaruh tidak sama. Pada perlakuan umur pengkomposan terhadap pertumbuhan tanaman sawi berpengaruh nyata pada tinggi $(\mathrm{cm})$, berat basah $(\mathrm{g})$ dan berat kering (g) tanaman sawi, sedangkan pada pertumbuhan jumlah daun tanaman sawi berpengaruh tidak nyata. Untuk perlakuan dosis kompos campuran tanah pasca tambang sebagai media tanam tanaman sawi berpengaruh nyata terhadap perumbuhan tinggi $(\mathrm{cm})$,
Helai daun, berat basah (g) dan berat kering $(\mathrm{g})$.

Sedangkan perlakuan interaksi dosis dan umur pengkomposan terhadap pertumbuhan tinggi, jumlah daun dan berat tanaman sawi saat panen memberikan repon berbeda. Pada pertumbuhan tinggi tanaman perlakuan umur pengkomposan dan dosis kompos pada media tanam tanah pasca tambang tanaman sawi tidak ada interaksi, hal ini dimungkinkan penyebabnya adalah proses dekomposisi kompos masih berlangsung atau berjalan dengan lambat. Hasil pengamatan mengasilkan nilai tertinggi rata - rata tanaman sawi pada umur pengkomposan 3 minggu dan dosis 60 ton/ha, ini menjelaskan bahwa proses pembentukan unsur nitrogen terus terjadi sampai 4 minggu setelah tanam.

Sedangkan pada pertumbuhan helai daun tanaman sawi interaksi dari perlakuan umur pengkomposan dan dosis kompos pada media tanam tanah pasca tambang memberikan pengaruh nyata, dilihat dari perhitungan uji BNT $5 \%$, grafik 4.6 maka terlihat jelas pengaruh interaksi perlakuan tersebut saat 4 minggu setelah tanam dimana interaksi perlakuan dosis 60 ton/ha umur pengkomposan 9 dan 12 minggu menunjukkan peningkatan helai daun di banding dengan perlakuan yang lain.

Dampak interaksi perlakuan umur pengkomposan dan dosis kompos pada pertumbuhan berat basah dan berat kering memberikan pengaruh nyata, dilihat dari hasil perhitungan uji BNT 5 $\%$, grafik 4.6 dan 4.7 maka terlihat jelas pengaruh interaksi perlakuan tersebut baik pada berat basah dan kering, dimana interaksi perlakuan dosis 60 ton/ha umur pengkomposan 9 dan 12 minggu menunjukkan peningkatan berat di banding yang lain. Penambahan dosis pupuk organik sampah rumah tangga pada tanah pasca tambang batubara belum menemukan titik optimal tetapi 
dari grafik masih menunjukkan garis bergerak vertikal ke atas, sehingga masih dimungkinkan hasil yang maksimal.

Menurut pangamatan peneliti bahwa pengunaan komposter FIFO sebagai tempat pengkomposan pupuk organik sampah rumah tangga dapat direkomendasi dalam menjaga keragaman kematangan kompos $(\mathrm{C} / \mathrm{N})$, peneliti berpendapat bahwa penambahan dosis pupuk organik dengan tanah pasca tambang positif memberikan peningkatan kualitas kesuburan pada tanah pasca tambang.

\section{KESIMPULAN}

Kesimpulan dari hasil penelitian adalah 1) Umur pengkomposan berpengaruh nyata terhadap pertumbuhan tanaman sawi pada tinggi $(\mathrm{cm})$, berat basah (g) dan berat kering (g) tanaman sawi, berpengaruh tetapi tidak nyata pada pertumbuhan jumlah daun tanaman sawi. 2) Dosis kompos campuran tanah pasca tambang sebagai media tanam tanaman sawi berpengaruh nyata terhadap perumbuhan tinggi $(\mathrm{cm})$, Helai daun, berat basah (g) dan berat kering (g). 3) Interaksi antara umur pengkomposan dan dosis pupuk organik pada media tanam tanah pasca tambang memberikan pengaruh nyata terhadap pertumbuhan jumlah daun, berat basah dan berat kering tanaman sawi, tetapi berpengaruh tidak nyata pada pertumbuhan tinggi tanaman sawi. 4) Pupuk organik sampah rumah tangga dengan umur pengkomposan 12 minggu dan dosis 60 ton/ha memberikan hasil yang paling tinggi, yaitu tinggi rata rata $35,17 \mathrm{~cm}$, jumlah daun 16 helai, berat basah 60,27 g, dan berat kering 28,55 g pada tanaman sawi.

\section{DAFTAR PUSTAKA}

Abdurrohim, O. (2008). Pengaruh
Kompos Terhadap Ketersediaan

Hara Dan Produksi Tanaman

Caisin Pada Latosol Dari Gunung Sindur. IPB Repository.

Apong Sandrawati, Emma Trinurani Sofyan, \& Oviyanti Mulyani. (2007). Pengaruh Kompos Sampah Kota Dan Pupuk Kandang Sapi Terhadap Sifat Kimia Tanah Dan Hasil Tanaman Jagung Manis (Zea mays saccharata) Pada Fluventic Eutrudepts Asal Jatinangor Kabupaten Sumedang. Universitas Padjadjaran. Fakultas Pertanian. Bandung.

Artiningsih, N. K. A. (2008, August 2). Peran Serta Masyarakat Dalam Pengelolaan Sampah Rumah Tangga (Studi Kasus di Sampangan dan Jomblang, Kota Semarang). Universitas Diponegoro.

Badan Standardisasi Nasional. (2004). Spesifikasi kompos dari sampah organik domestik. Badan Standardisasi Nasional. Jakarta.

Dewi, Y. S., \& Treesnowati. (2012). Pengolahan Sampah Skala Rumah Tangga Menggunakan Metode Komposting. Jurnal Ilmiah Fakultas Teknik LIMIT'S, 8(2), 35-48.

Endhah, R. (2017). Pengaruh Dosis Dan Waktu Aplikasi Azolla Pinnata Terhadap Pertumbuhan Dan Produktivitas Tanaman Kedelai (Glycine $\max$ (L.) Merril). UNIVERSITAS NUSANTARA PGRI KEDIRI.

Erawan, D., Yani, W. O., \& Bahrun, A. (2013). Pertumbuhan Dan Hasil Tanaman Sawi (Brassica juncea L.) 
Pada Berbagai Dosis Pupuk Urea. Agroteknos, 3(1), 19-25.

Guntoro, D., Purwono, \& Sarwono. (2003). Pengaruh Pemberian Kompos Bagase terhadap Serapan Hara dan Pertumbuhan Tanaman Tebu (Saccharum ojficinarum L.). Buletin Agronomi IPB, 31(3), 112119.

Gustia, H. (2014). Pengaruh Penambahan Sekam Bakar Pada Media Tanam Terhadap Pertumbuhan Dan Produksi Tanaman Sawi (Brassica juncea L.). E-Journal WIDYA, 1(1), 12-17.

Haryanto, E., Suhartini, T., Rahayu, E., \& Sunarjono, H. (2007). Sawi \& Selada (XI). Jakarta.

Heriyanto, N. M., \& Siregar, C. A. (2007). Biomasa Dan Kandungan Karbon Pada Hutan Tanaman Tusam ( Pinus merkusii Jungh et de Vriese ) Umur Lima Tahun Di Cianten, Bogor, Jawa Barat ( Biomass and Carbon Stock of Pine Plantation in Cianten , Bogor, West Java ). Jurnal Penelitian Hutan Dan Konservasi Alam, 4(1), 1-7.

Maryanto, \& Rahmi, A. (2015). Pertumbuhan Dan Hasil Tanaman Tomat ( Lycopersicum esculentum Mill ) Varietas Permata Tanaman Tomat. AGRIFOR, XIV(1), 87-94.

Muhammad, A. N. (2013). Pengaruh Penggunaan Dosis Pupuk Urea dan Dosis Pupuk Kompos Terhadap Pertumbuhan dan Hasil Tanaman Sawi ( Brassica chinensis L.). Eprints.Upnjatim.Ac.Id. UPN Veteran Jatim.
Nurlaela, Saleng, A., \& Patittingi, F. (2014). Tanggung Jawab Hukum Reklamasi Lahan Bekas Pertambangan Pt.Kaltim Prima Coal Di Kabupaten Kutai Timur. EJurnal Pasca Sarjana UNHAS, 3(2), $1-13$.

Nurullita, U., \& Budiyono. (2012). Lama Waktu Pengomposan Sampah Rumah Tangga Berdasarkan Jenis Mikro Organisme Lokal (Mol) Dan Teknik Pengomposan. PROSIDING SEMINAR NASIONAL - LPPM UNIMUS 2012 Portalgaruda.org, 236-245.

Pitoyo. (2016, August 23). Pengomposan Pelepah Daun Salak (Salacca Edulis) Dengan Berbagai Macam Aktivator.

FAKULTAS PERTANIAN UNIVERSITAS MUHAMMADIYAH YOGYAKARTA.

Rukmana, R. (1994). Bertanam Petsai \& Sawi. Yogyakarta: Kanisius.

Siregar, S. (2015). Distribusi Pemasaran Pakcoy Berpola Kemitraan Dengan Supermarket Di P4s Agrofarm Cianjurprovinsi Jawa Barat. Politeknik Pertanian Negeri Payakumbuh.

Sudaryono, S. (2009). Tingkat Kesuburan Tanah ULTISOL Pada Lahan Ppertambangan Batubara Ssangatta, Kalimantan Timur. JURNAL TEKNOLOGI LINGKUNGAN, 10(3), 337-346.

Suleman, D, C., Pomalingo, N., \& NURMI. (2013). Pertumbuhan Dan Produksi Tanaman Sawi (Brassica juncea L.) Dengan Pemberian Dosis 
Pupuk Organik Kotoran Ayam. eprints.ung.ac.id. Unversitas Negeri Gorontalo.

Sulistyawati, E., Mashita, N., \& Choesin, D. N. (2008). Hasil Pengomposan Sampah Organik Rumah Tangga Effect of Decomposer Agents on the Quality of. Makalah dipresentasikan pada Seminar Nasional Penelitian Lingkungan di Perguruan Tinggi, 7 Agustus 2008 di Universitas Trisakti, Jakarta.

Sunarjono, H. (2008). Berkebun 21 Jenis Tanaman Buah (VI). Jakarta: Penebar Swadaya.
Wahid, T. S., \& dkk. (2013). Optimalisasi Pertumbuhan Dan Produksi Tanaman Sawi Hijau Brassica juncea L. Secara Hidroponik Dengan Pemberian Berbagai Bahan Organik Cair. E Jurnal Unhas.ac.id, 9(3), 1-11.

Yunindanova, M., Agusta, H., \& Asmono, D. (2013). Pengaruh Tingkat Kematangan Kompos Tandan Kosong Sawit Dan Mulsa Limbah Padat Kelapa Sawit Terhadap Produksi Tanaman. Jurnal Ilmu Tanah Dan Agroklimatologi, 10(2), 91-100. 